\title{
Nonmetastatic pancreatic cancer
}

\section{Improved survival with chemoradiotherapy $>40$ Gy after systemic treatment}

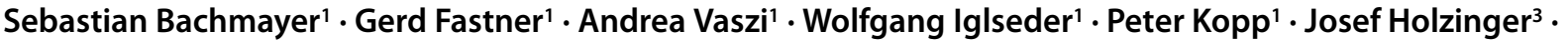 \\ Adam Dinnewitzer ${ }^{3}$. Gabriel Rinnerthaler ${ }^{4}$ Simon Peter Gampenrieder ${ }^{4}$ Klaus Emmanuel ${ }^{3}$. Richard Greil ${ }^{4}$. \\ Felix Sedlmayer ${ }^{1,2} \cdot$ Franz Zehentmayr $^{1,2}$
}

Received: 4 September 2017 / Accepted: 12 February 2018 / Published online: 1 March 2018

(c) The Author(s) 2018. This article is an open access publication.

\begin{abstract}
Purpose The role of radiotherapy (RT) for nonmetastatic pancreatic cancer is still a matter of debate since randomized control trials have shown inconsistent results. The current retrospective single-institution study includes both resected and unresected patients with nonmetastasized pancreatic cancer. The aim is to analyze overall survival (OS) after irradiation combined with induction chemotherapy.

Patients and methods Of the 73 patients with nonmetastatic pancreatic cancer eligible for the present analysis, 42 ( $58 \%)$ patients had adjuvant chemoradiotherapy (CRT), while $31(42 \%)$ received CRT as primary treatment. In all, $65(89 \%)$ had chemotherapy at any time before, during, or after RT, and $39(53 \%)$ received concomitant CRT. The median total dose was $50 \mathrm{~Gy}$ (range $12-77 \mathrm{~Gy}$ ), while $61(84 \%)$ patients received $>40 \mathrm{~Gy}$.

Results With a median follow-up of 22 months (range 1.2-179.8 months), 14 (19\%) are still alive and 59 (81\%) of the patients have died, whereby $51(70 \%)$ were cancer-related deaths. Median OS and the 2-year survival rate were 22.9 months (1.2-179.8 months) and 44\%, respectively. In addition, $61(84 \%)$ patients treated with $>40 \mathrm{~Gy}$ had a survival advantage (median OS 23.7 vs. 17.3 months, $p=0.026$ ), as had patients with 4 months minimum of systemic treatment (median OS 27.5 vs. 14.3 months, $p=0.0004)$.

Conclusion CRT with total doses $>40 \mathrm{~Gy}$ after induction chemotherapy leads to improved OS in patients with nonmetastatic pancreatic cancer.
\end{abstract}

Keywords Pancreatic cancer · Adjuvant chemotherapy · Overall survival $\cdot$ Retrospective analysis $\cdot$ Surgery

Electronic supplementary material The online version of this article (https://doi.org/10.1007/s00066-018-1281-7) contains supplementary material, which is available to authorized users.

Franz Zehentmayr, M.D., M.Sc.

f.zehentmayr@salk.at

1 Department of Radiotherapy and Radio-oncology, University Hospital Salzburg, Paracelsus Medical University, Salzburg, Austria

$2 \operatorname{radART}$ Institute for Research and Development of Advanced Radiation Technologies, Paracelsus Medical University, Salzburg, Austria

3 University Clinic of Surgery, University Hospital Salzburg, Paracelsus Medical University, Salzburg, Austria

4 IIIrd Medical Department, University Hospital Salzburg, Paracelsus Medical University, Salzburg, Austria 


\section{Nichtmetastasiertes Pankreaskarzinom}

Verbessertes Überleben durch Chemoradiotherapie mit >40 Gy nach systemischer Behandlung

\section{Zusammenfassung}

Hintergrund Die Bedeutung der Radiotherapie (RT) in der Behandlung des nichtmetastasierten Pankreaskarzinoms ist nach wie vor umstritten, zumal die Ergebnisse randomisierter Studien inkonklusiv sind. Die vorliegende retrospektive Studie inkludiert sowohl operierte als auch nichtoperierte Patienten mit nichtmetastasiertem Pankreaskarzinom. Primärer Endpunkt der Analyse ist das Gesamtüberleben (OS) nach Bestrahlung und vorangegangener Induktionschemotherapie.

Patienten und Methoden Analysiert wurden 73 Patienten mit nichtmetastasiertem Pankreaskarzinom. Von diesen hatten $42(58 \%)$ eine adjuvante Chemoradiotherapie (CRT). Eine CRT als primäre Behandlung erhielten 31 (42\%) nichtoperierte Patienten. Eine Chemotherapie vor, während oder nach RT hatten 65 (89\%), 39 (53\%) bekamen eine konkomittante CRT. Die mediane Gesamtdosis war 50 Gy (Spanne 12-77 Gy). Mehr als 40 Gy erhielten 61 Patienten (84\%).

Ergebnisse Bei einer medianen Nachsorgedauer von 22 Monaten (Spanne 1,2-179,8 Monate) waren 59 (81\%) Patienten verstorben, $14(19 \%)$ leben noch. Die Todesursache war bei 51 (70\%) Patienten ihre Tumorerkrankung. Das mediane Überleben betrug 22,9 Monate (Spanne 1,2-179,8 Monate), das 2-Jahres-Überleben 44\%. Insgesamt 61 (84\%) Patienten, die mit $>40$ Gy behandelt wurden, hatten einen Überlebensvorteil (medianes OS 23,7 vs. 17,3 Monate; $p=0,026$ ), ebenso Patienten nach mindestens 4 Monaten Systemtherapie (medianes OS 27,5 vs. 14,3 Monate; $p=0,0004$ ).

Schlussfolgerung Eine CRT mit Gesamtdosen $>40$ Gy nach Induktionschemotherapie verbessert das OS bei Patienten mit nichtmetastasiertem Pankreaskarzinom.

Schlüsselwörter Pankreaskarzinom · Adjuvante Chemotherapie $\cdot$ Gesamtüberleben $\cdot$ Retrospektive Analyse $\cdot$ Operation

\begin{tabular}{|c|c|}
\hline \multicolumn{2}{|c|}{ Abbreviations } \\
\hline ASCO & American Society of Clinical Oncology \\
\hline CT & Chemotherapy \\
\hline CRT & Chemoradiotherapy \\
\hline EBRT & External beam radiotherapy \\
\hline EORTC & $\begin{array}{l}\text { European Organisation for Research and Treat- } \\
\text { ment of Cancer }\end{array}$ \\
\hline ESPAC & European Study Group for Pancreatic Cancer \\
\hline EQD2 & Biologically equivalent dose in $2 \mathrm{~Gy}$ fractions \\
\hline GERCOR & $\begin{array}{l}\text { Groupe Coopérateur Multidisciplinaire en On- } \\
\text { cologie }\end{array}$ \\
\hline GITSG & Gastrointestinal Tumor Study Group \\
\hline HR & Hazard ratio \\
\hline IMRT & Intensity-modulated radiotherapy \\
\hline IOERT & Intraoperative radiotherapy with electrons \\
\hline LAPC & Locally advanced pancreatic cancer \\
\hline $\mathrm{mOS}$ & Median overall survival \\
\hline mRT-dose & Median radiation dose \\
\hline MVA & Multivariate analysis \\
\hline NCDB & National Cancer Database \\
\hline NR & Not reported \\
\hline NS & Not significant \\
\hline OS & Overall survival \\
\hline RT & Radiotherapy \\
\hline UICC & Union Internationale Contre le Cancer \\
\hline
\end{tabular}

\section{Introduction}

In Europe, a total of 87,400 deaths due to pancreatic cancer were predicted for 2017, which amounts to approximately $6 \%$ of all cancer deaths [1]. These numbers indicate the aggressiveness of this disease and its dismal prognosis. Surgery is still the cornerstone of curative treatment. Unfortunately, only $20 \%$ of the patients are resectable at the time of diagnosis, $30 \%$ present with unresectable locally advanced disease, and $50 \%$ of the patients already have distant metastases [2].

While adjuvant chemotherapy (CT) is undisputed, the addition of radiotherapy is recommended only for subgroups of patients. According to the ASCO guidelines, it should be offered to patients with $\mathrm{N} 1$ and/or R1 status [3, 4], whereas in Germany adjuvant chemoradiotherapy (CRT) is restricted to clinical trials only [5]. The prospective studies that informed this conceptual framework were conducted between 1985 [6] and 2004 [7]. Based on an outdated radiation treatment schedule-40 Gy split course - the European Study Group for Pancreatic Cancer (ESPAC) came to the conclusion that CRT is not only inferior to CT but detrimental with respect to overall survival (OS). In the latest study, 50.4 Gy total dose in the CRT arm were administered, which resulted in OS rates similar to CT alone [8].

For the treatment of locally advanced pancreatic cancer (LAPC) guidelines recommend initial CT followed by CRT only for those patients without systemic progression [3, 4]. The prospective randomized control trials in the field published in the past decade [9-11] were conducted with 
Table 1 Patient characteristics

\begin{tabular}{|c|c|c|c|}
\hline \multicolumn{4}{|c|}{ Patient characteristics at baseline $N=73$} \\
\hline \multirow[t]{2}{*}{$\overline{\operatorname{Sex}(n)}$} & Male & 37 & $51 \%$ \\
\hline & Female & 36 & $49 \%$ \\
\hline \multirow{2}{*}{$\begin{array}{l}\text { Age at diagnosis } \\
\text { (years) }\end{array}$} & Median & 66.9 & - \\
\hline & Range & $45.6-83.7$ & - \\
\hline \multirow{2}{*}{$\begin{array}{l}\text { Pathological } \\
\text { confirmation }\end{array}$} & Yes & 64 & $88 \%$ \\
\hline & No & 9 & $12 \%$ \\
\hline \multirow[t]{4}{*}{ Tumor location $(n)$} & Papilla of vater & 4 & $6 \%$ \\
\hline & $\begin{array}{l}\text { Head or uncinate } \\
\text { process }\end{array}$ & 47 & $64 \%$ \\
\hline & Body or tail & 19 & $26 \%$ \\
\hline & Neck & 3 & $4 \%$ \\
\hline \multirow[t]{4}{*}{$\mathrm{T}(n)$} & $\mathrm{T} 1$ & 1 & $1 \%$ \\
\hline & $\mathrm{T} 2$ & 4 & $5 \%$ \\
\hline & $\mathrm{T} 3$ & 40 & $55 \%$ \\
\hline & $\mathrm{T} 4$ & 28 & $38 \%$ \\
\hline \multirow[t]{2}{*}{$\mathrm{N}(n)$} & No & 21 & $29 \%$ \\
\hline & N1 & 52 & $71 \%$ \\
\hline \multirow[t]{2}{*}{$\mathrm{M}(n)$} & M0 & 72 & $99 \%$ \\
\hline & Mx & 1 & $1 \%$ \\
\hline \multirow{2}{*}{$\begin{array}{l}\text { Involvement of either } \\
\text { duodenum, spleen or } \\
\text { adrenal glands }(n)\end{array}$} & Yes & 14 & $19 \%$ \\
\hline & No & 59 & $81 \%$ \\
\hline \multirow[t]{4}{*}{ Histologic type $(n)$} & Papilla of vater & 4 & $5 \%$ \\
\hline & Adenocarcinoma & 57 & $78 \%$ \\
\hline & $\begin{array}{l}\text { Neuroendocrine } \\
\text { tumor }\end{array}$ & 2 & $3 \%$ \\
\hline & Unknown & 10 & $14 \%$ \\
\hline \multirow[t]{4}{*}{ Grading $(n)$} & G1 & 3 & $4 \%$ \\
\hline & $\mathrm{G} 2$ & 38 & $52 \%$ \\
\hline & G3 & 18 & $25 \%$ \\
\hline & Gx & 14 & $19 \%$ \\
\hline \multirow[t]{5}{*}{ UICC stage $(n)$} & IA & 1 & $1 \%$ \\
\hline & IB & 1 & $1 \%$ \\
\hline & IIA & 7 & $10 \%$ \\
\hline & IIB & 36 & $49 \%$ \\
\hline & III & 28 & $38 \%$ \\
\hline \multirow{2}{*}{$\begin{array}{l}\text { Karnofsky } \\
\text { performance score }(n)\end{array}$} & $\geq 70$ & 57 & $78 \%$ \\
\hline & $<70$ & 16 & $22 \%$ \\
\hline \multirow{2}{*}{$\begin{array}{l}\text { Local progression } \\
\text { during CT } \\
\text { before RT }(n)\end{array}$} & Yes & 19 & $26 \%$ \\
\hline & No & 54 & $74 \%$ \\
\hline
\end{tabular}

$C T$ chemotherapy, $R T$ radiotherapy

radiation doses of 46 to $60 \mathrm{~Gy}$. The study design of the latest of these three studies included a period of 4 months of CT before CRT with $54 \mathrm{~Gy}$. The two treatment regimens were iso-effective with respect to OS but locoregional control and time to retreatment was significantly better in the CRT $\operatorname{arm}[11]$.

Taken together, the role of radiotherapy both for resectable and unresectable pancreatic cancer is still under
Table 2 Treatment characteristics

\begin{tabular}{|c|c|c|c|c|}
\hline \multicolumn{5}{|c|}{ Treatment characteristics $N=73$} \\
\hline \multirow[t]{7}{*}{ Surgery } & \multirow[t]{2}{*}{ Resection } & Yes & 42 & $58 \%$ \\
\hline & & No & 31 & $42 \%$ \\
\hline & \multirow{2}{*}{$\begin{array}{l}\text { Type of } \\
\text { resection }\end{array}$} & Whipple & 27 & $37 \%$ \\
\hline & & Other & 15 & $21 \%$ \\
\hline & \multirow{3}{*}{$\begin{array}{l}\text { Resection } \\
\text { margin status }\end{array}$} & R0 & 20 & $27 \%$ \\
\hline & & $\mathrm{R} 1$ & 21 & $29 \%$ \\
\hline & & $\mathrm{R} 2$ & 1 & $1 \%$ \\
\hline \multirow{8}{*}{$\begin{array}{l}\text { Radio- } \\
\text { therapy }\end{array}$} & \multirow[t]{2}{*}{ IOERT $(n)$} & Yes & 18 & $25 \%$ \\
\hline & & No & 55 & $75 \%$ \\
\hline & \multirow[t]{3}{*}{$\operatorname{EBRT}(n)$} & Yes & 61 & $84 \%$ \\
\hline & & No & 12 & $16 \%$ \\
\hline & & $\begin{array}{l}\text { Median } \\
\text { single dose } \\
\text { (range) }\end{array}$ & $\begin{array}{l}1.8 \mathrm{~Gy} \\
(1.6-2.0 \mathrm{~Gy})\end{array}$ & - \\
\hline & \multirow[t]{3}{*}{$\begin{array}{l}\text { EQD2 } \\
(\text { EBRT + IORT) }\end{array}$} & $\begin{array}{l}\text { Median total } \\
\text { dose (range) }\end{array}$ & $\begin{array}{l}50 \mathrm{~Gy} \\
(12-77 \mathrm{~Gy})\end{array}$ & - \\
\hline & & $<40 \mathrm{~Gy}$ & 12 & $16 \%$ \\
\hline & & $\geq 40$ Gy $(n)$ & 61 & $84 \%$ \\
\hline \multirow{6}{*}{$\begin{array}{l}\text { Chemo- } \\
\text { therapy }\end{array}$} & \multirow{2}{*}{$\begin{array}{l}\text { Concomitant } \\
\text { CRT }\end{array}$} & Yes & 39 & $53 \%$ \\
\hline & & No & 34 & $47 \%$ \\
\hline & \multirow[t]{2}{*}{ CT before RT } & $\begin{array}{l}<4 \text { months } \\
\text { or none }\end{array}$ & 29 & $40 \%$ \\
\hline & & $>4$ months & 44 & $60 \%$ \\
\hline & \multirow{2}{*}{$\begin{array}{l}\text { CT before, } \\
\text { during or after } \\
\text { RT }\end{array}$} & Yes & 65 & $89 \%$ \\
\hline & & No & 8 & $11 \%$ \\
\hline
\end{tabular}

IOERT intraoperative radiotherapy with electrons, EBRT external beam radiotherapy, EQD2 biologically equivalent dose in $2 \mathrm{~Gy}$ fractions, $C T$ chemotherapy, $R T$ radiotherapy, $C R T$ chemoradiotherapy

investigation. Due to a probability of $30 \%$ for micrometastases at the time of diagnosis [12] patients with nonmetastasized pancreatic cancer may progress early at distant sites, which impairs clinical outcome. Simultaneously, locoregional recurrence may also lead to death [13].

The current study includes both resected and unresected patients with nonmetastasized pancreatic cancer. Its aim is to analyze OS following irradiation combined with induction chemotherapy in the therapeutic setting of a European tertiary referral center.

\section{Materials and methods}

\section{Patients}

Between 1982 and 2016, 150 patients with pancreatic and periampullary cancer were referred to our department for radiation therapy. In all, 77/150 (51\%) patients were excluded from the present analysis mainly for distant metastasis at the time of diagnosis. For the current analysis we included 73 patients who were referred since 1998, when 
intraoperative radiotherapy with electrons (IOERT) as well as 3D CRT were fully implemented. The primary endpoint was overall survival (OS).

Patients' characteristics are described in Table 1. Patients were staged according to the $6^{\text {th }}$ edition of the TNM system before 2010. When reviewing the charts in 2016 we used the $7^{\text {th }}$ edition as a reference knowing that the two systems were identical with respect to pancreatic cancer. The majority of patients were classified as T3 (55\%) and T4 (38\%), respectively. Out of T4 tumors, 14 (19\%) patients presented with involvement of duodenum, spleen or adrenal glands. In total, 66/73 (90\%) patients presented with Union internationale contre le cancer (UICC) stages IIB or III. In 47/73 $(64 \%)$ cases, the primary tumor was located in the head of the pancreas or the uncinate process, in $4 / 73(6 \%)$ the papilla of vater and in $19 / 73(26 \%)$ in the body or tail. In addition, $3 / 73$ (4\%) were found in the neck of the pancreas. At the start of radiation treatment, 19/73 (26\%) patients presented with local progression after induction CT. Disease progression was diagnosed by imaging (computed tomography, MRI or PET-CT scans) with histological confirmation at the discretion of the treating physician.

\section{Treatment}

In resectable patients $(42 / 73,58 \%)$, CRT was applied as adjuvant treatment, while being the primary approach for the $31 / 73(42 \%)$ patients who presented with locally advanced disease deemed to be unresectable. Treatment characteristics are summarized in Table 2.

Surgery was performed in curative intention and resulted in 20/42 (48\%) histologically complete (R0) and 21/42 (50\%) incomplete (R1) resections. In 1/42 (2\%) patient surgery was macroscopically incomplete (R2). Pathology reports were re-evaluated and-in accordance with Verbeke et al.- resection was regarded as incomplete if tumor cells were found within $1 \mathrm{~mm}$ of the resection margin [14].

Radiotherapy was performed as intraoperative radiotherapy with electrons (IOERT) and/or external beam treatment. IOERT was delivered by means of a standard LINAC (median $8 \mathrm{MeV}$, range $6-18 \mathrm{MeV}$ ). The energy was chosen according to dose depth (median $2.2 \mathrm{~cm}$, range $0.9-4 \mathrm{~cm}$ ) determined by ultrasound. The tube diameter was adjusted to tumor bed dimensions (median $3.7 \mathrm{~cm}$, range $2.0-5.5 \mathrm{~cm}$ ). The median $90 \%$ isodose was 9 Gy (range $7-18 \mathrm{~Gy}$ ). A total of 18/73 (24\%) patients received single fraction IOERT during surgery, and out of these, 3 patients in the course of explorative laparotomies. The median IOERT dose (Dmax) was $10 \mathrm{~Gy}$ (range 8-20Gy), resulting in a median total equivalent dose (EQD2) of $17 \mathrm{~Gy}$ (range 12-49Gy) in the tumor bed.

EBRT was usually performed with $15 \mathrm{MV}$ photons (range 15-25 MV) in conventional 3D-box technique (three or four portals). The median single dose was $1.8 \mathrm{~Gy}$ (range 1.6-2Gy). The dose-volume constraints were set at the usual levels with maximum doses of small intestine as well as myelon at $45 \mathrm{~Gy}$, the stomach at $50 \mathrm{~Gy}$, V50 for the kidney $<30 \%$ [15]. A total of $61 / 73(84 \%)$ patients received EBRT, one of these was treated with IMRT. In 43/73 (59\%) patients, the planning target volume included the regional lymphatic drain. The median total EQD2 (EBRT + IOERT) for all patients was 50 Gy (range 12-77 Gy); $61 / 73$ (84\%) patients received more than 40 Gy EQD2 (median 50 Gy, range 44-77 Gy).

The chemotherapeutic regimens were based on 5-FU (or capecitabine) or gemcitabine. In all, 26/42 resected patients received $\mathrm{CT}$ before $\mathrm{RT}$ in two possible therapy sequences: $\mathrm{CT}+$ surgery $+(\mathrm{C}) \mathrm{RT}(n=2)$ or surgery $+\mathrm{CT}+(\mathrm{C}) \mathrm{RT}(n=$ 24). Thus, induction chemotherapy in the strict sense was applied in 2 cases with the intention to achieve operability. A total of 18 patients had gemcitabine mono $\left(1000 \mathrm{mg} / \mathrm{m}^{2}\right.$ on day 1,3 out of 4 weeks), 3 GEMOX (gemcitabine $1000 \mathrm{mg} / \mathrm{m}^{2}$, oxaliplatin $100 \mathrm{mg} / \mathrm{m}^{2}$, every 2 weeks), 3 FOLFIRINOX (oxaliplatin $85 \mathrm{mg} / \mathrm{m}^{2}$, irinotecan $180 \mathrm{mg} / \mathrm{m}^{2}$, leucovorin $400 \mathrm{mg} / \mathrm{m}^{2}, 5$-FU bolus $400 \mathrm{mg} / \mathrm{m}^{2}$, 5-FU continuous $2400 \mathrm{mg} / \mathrm{m}^{2}$ over $46 \mathrm{~h}$, every 2 weeks), one patient had 5-FU/leucovorin $\left(425 \mathrm{mg} / \mathrm{m}^{2}, 20 \mathrm{mg} / \mathrm{m}^{2}\right.$, weekly) and another one EVANS (doxorubicin $50 \mathrm{mg} / \mathrm{m}^{2}$ on day 1 , cyclophosphamide $1000 \mathrm{mg} / \mathrm{m}^{2}$ on day 1 , cisplatin $25 \mathrm{mg} / \mathrm{m}^{2}$ on days $1-5$, etoposide $50 \mathrm{mg} / \mathrm{m}^{2}$ on days $1-5$, every 3 weeks). The median number of cycles was 6 (range $1-17)$. In the group of unresected patients $27 / 31$ had CT before RT: 6 gemcitabine mono, 10 GEMOX, 10 FOLFIRINOX and one EVANS. The median number of cycles was 4 (range 3-11).

CRT was administered to $39 / 73$ (54\%) patients, while $65 / 73$ (89\%) patients had chemotherapy at any time (prior, following or concomitant to irradiation).

\section{Equivalent total dose in $\mathbf{2}$ Gy fractions (EQD2)}

The generally accepted $\alpha / \beta$ values for gastrointestinal tissues range from $6-13 \mathrm{~Gy}[16,17]$. A recent publication by Unkel et al. analyzed clonogenic assays in nine pancreatic cancer cell lines. The median $\alpha / \beta$ value extrapolated from these experiments was 9.4 Gy (range 1.85-191.58 Gy; [18]). Taking into account the considerable heterogeneity of these numbers EQD2 in the current study was calculated with an $\alpha / \beta$ value of 10 .

\section{Statistics}

OS was defined as the time from diagnosis until death or last follow-up and estimated by the Kaplan-Meier method. The patient cohort was divided into groups according to EQD2: dose splits were set at $40 \mathrm{~Gy}, 45 \mathrm{~Gy}, 50 \mathrm{~Gy}$, and $55 \mathrm{~Gy}$. These 
Fig. 1 Overall survival in 73 patients with nonmetastatic pancreatic cancer

Fig. 2 Overall survival is significantly improved in 61 patients with radiotherapy doses $>40 \mathrm{~Gy}$ compared to the 12 patients who received $<40 \mathrm{~Gy}$ (log-rank $p=0.027$ )
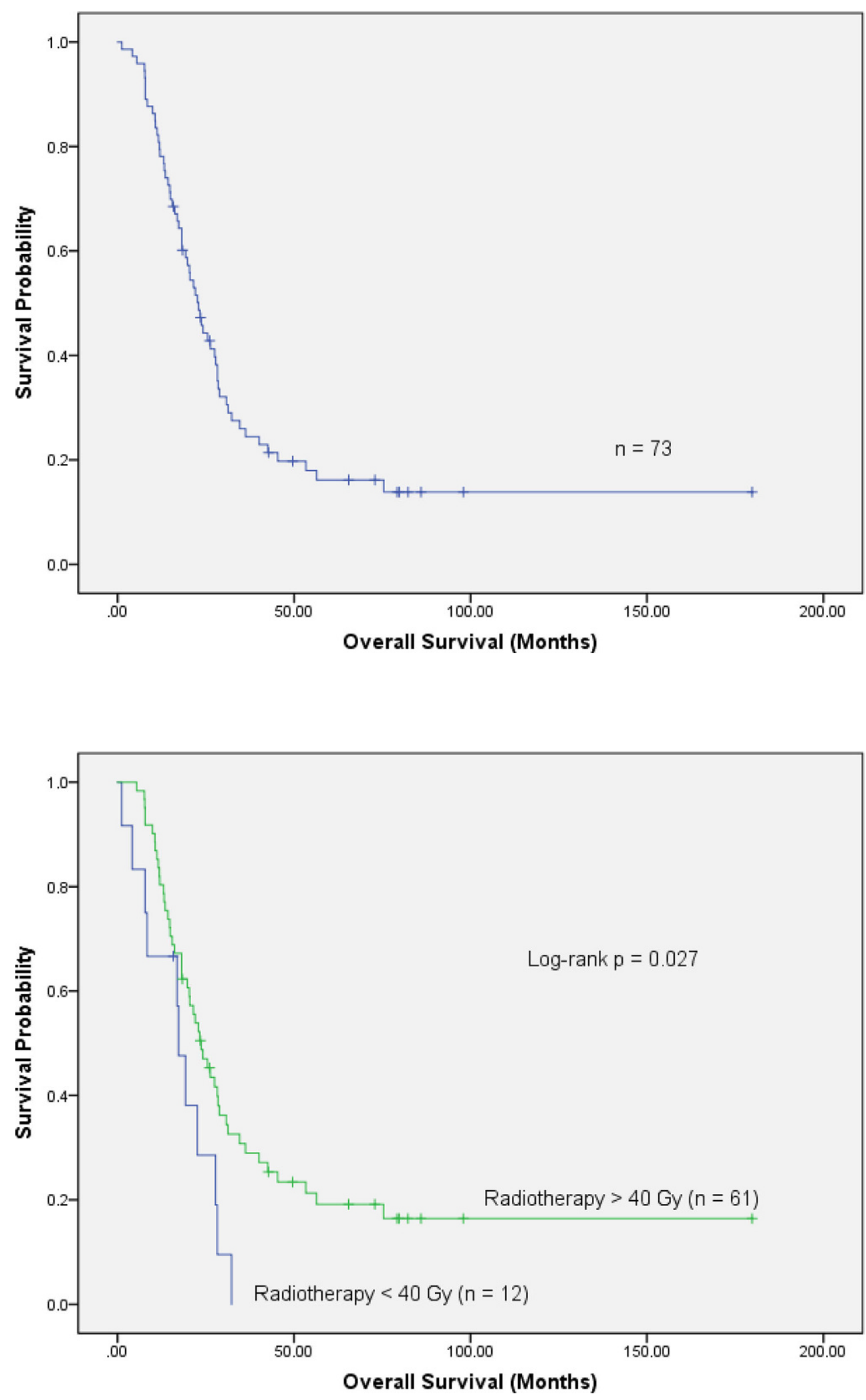
Fig. 3 Comparison of patients by duration of induction chemotherapy: overall survival is significantly better in 44 patients with $>4$ months than in 29 patients with $<4$ months $(\log -$ rank $p=0.0004)$

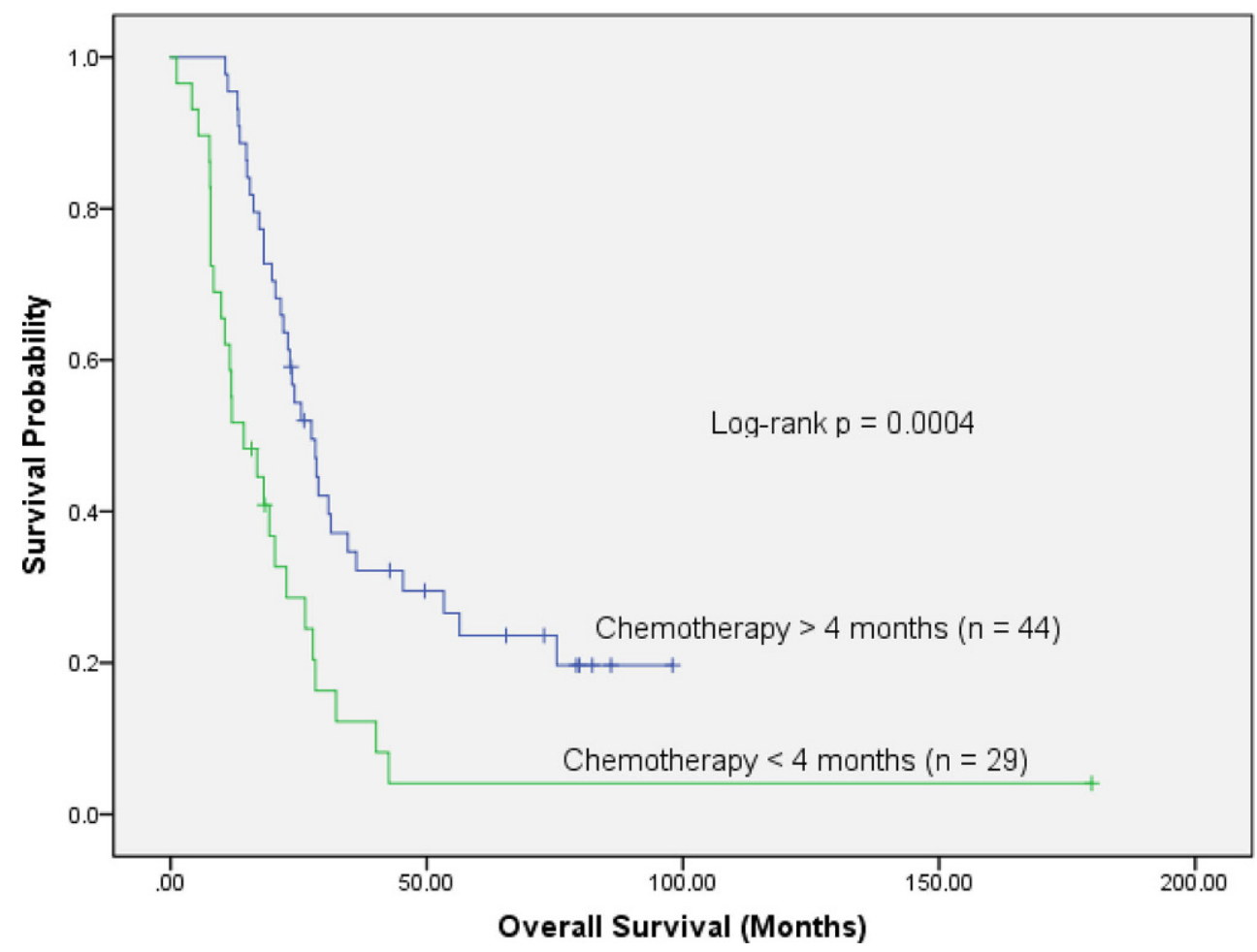

subgroups were compared by log-rank testing. In order to detect patient-related factors that are prognostically relevant with respect to OS, multivariate analyses (MVA) were performed by Cox regression (forward likelihood ratio). MVA models were calculated for resected and unresected patients separately. They included the following variables: sex, age at diagnosis, tumor location, T-stage, $\mathrm{N}$-stage, involvement of adjacent structures (i.e., duodenum, spleen, adrenal glands), histology, grading, UICC stage, Karnofsky performance score, local progression before RT. $P$-values of 0.05 with a $95 \%$ confidence interval were regarded as statistically significant. Data were analyzed with SPSSTM for Windows v 21.0.0.1.

\section{Results}

With a median follow-up of 22 months (range 1.2-179.8 months), 59/73 (81\%) of the patients died and 14/73 (19\%) are still alive. There were 51/73 (70\%) cancer-related deaths, 1/73 (1\%) patient died for septic multiple organ failure and $2 / 73(2 \%)$ died for cardiac reasons. In $5 / 73$ (7\%) patients, the medical charts were incomplete and no information could be obtained so that the cause of death remained unknown. The median OS for the whole patient cohort was 22.9 months, with 2- and 5-year survival rates of 44 and 16\%, respectively (Fig. 1). In the subgroup of resected patients, the corresponding numbers were 25.5 months, 52 and $20 \%$, while in unresected pa- tients median survival was 20.4 months, 2-year and 5-year survival rates were 34 and $13 \%$, respectively (log-rank $p=0.154)$.

Based on EQD2, patients were grouped into two dose bins with a threshold dose below (group 1) or above $40 \mathrm{~Gy}$ (group 2), respectively. Fig. 2 shows the comparison of $61 / 73(84 \%)$ patients in group 1 who were treated with at least 40 Gy EQD2 (median 50 Gy, range 44-77 Gy) compared to $12 / 73(16 \%)$ individuals (group 2) who received less than $40 \mathrm{~Gy}$ (median $17 \mathrm{~Gy}$, range $12-37 \mathrm{~Gy}$ ) for one of the following reasons: postsurgery complications (5), lack of compliance (2), M1 during chemotherapy (3), multiorgan failure due to infection (1). Additionally, one patient received previous irradiation for seminoma 26 years before he was diagnosed with pancreatic cancer. In group 1, the median OS was 23.7 months, and the 2- and 5-years survival rates amounted to 47 and $19 \%$, while in group 2 the respective numbers were 17.3 months, 19 and $0 \%(p=0.026)$. Of note, this difference remained significant within the cohort of the 42 patients who had received surgery: when treated with doses $>40 \mathrm{~Gy}$, the median survival time, as well as the 2- and 5-year survival rates amounted to 27.5 months, 56 and $20 \%$, respectively, compared to 19.3 months, 23 and $0 \%$ in those patients with the lower dose $(p=0.028)$. For the 31 unresected patients no significant difference could be detected $(p=0.073)$ : patients with $>40 \mathrm{~Gy}$ had a median, 2- and 5-years survival of 20.4 months, 37 and 14\%, compared to 4.2 months, $0 \%$ for those with lower doses. 
Fig. 4 Comparison by combined treatment modalities: overall survival is significantly better in 53 patients who received $>4$ months of chemotherapy followed by $>40$ Gy than in the other 20 patients who had $<4$ months of chemotherapy and/or $<40 \mathrm{~Gy}$ (log-rank $p=0.0002$ )

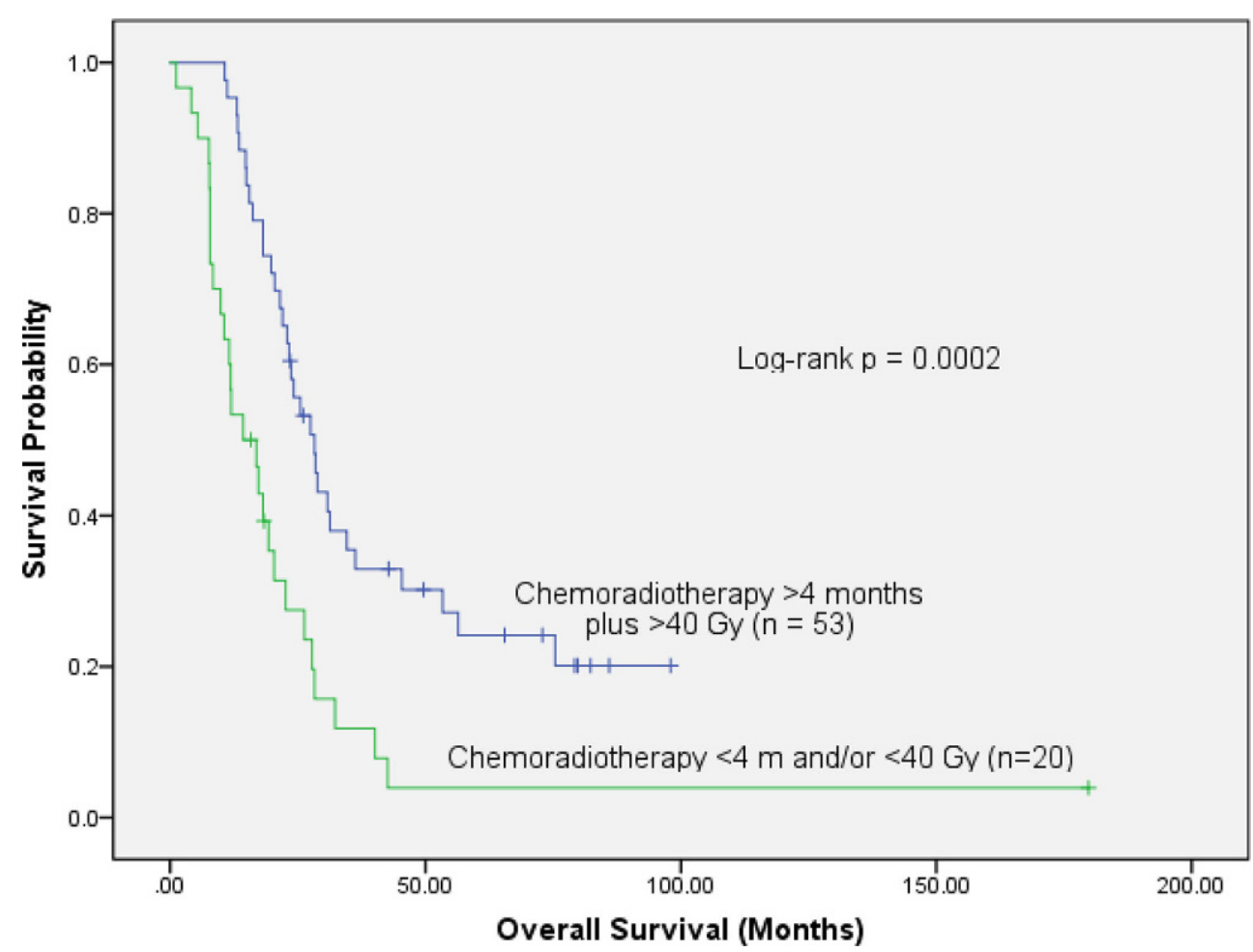

Table 3 Prognostic factors for overall survival

\begin{tabular}{|c|c|c|c|c|}
\hline \multicolumn{5}{|l|}{ Prognostic factors } \\
\hline & \multicolumn{2}{|c|}{ Resected patients } & \multicolumn{2}{|c|}{ Unresected patients } \\
\hline & UVA & MVA & UVA & MVA \\
\hline Sex & 0.091 & n.s. & 0.376 & n.s. \\
\hline Age at diagnosis & 0.974 & n.s. & 0.660 & n.s. \\
\hline Tumor location & 0.287 & n.s. & 0.846 & n.s. \\
\hline $\mathrm{T}$ & 0.269 & n.s. & 0.992 & n.s. \\
\hline $\mathrm{N}$ & 0.226 & n.s. & 0.162 & n.s. \\
\hline Involvement of either duodenum, spleen or adrenal glands & 0.046 & n.s. & 0.778 & n.s. \\
\hline Histologic type & 0.127 & n.s. & 0.634 & n.s. \\
\hline Grading & 0.051 & n.s. & 0.300 & n.s. \\
\hline UICC stage & 0.088 & n.s. & 0.634 & n.s. \\
\hline Karnofsky performance score & 0.629 & n.s. & 0.737 & n.s. \\
\hline Local progression during induction chemotherapy & 0.726 & n.s. & 0.014 & 0.023 \\
\hline
\end{tabular}

$U V A$ univariate analysis, MVA multivariate analysis, n.s. not significant

We also compared survival between patients with 4 months of chemotherapy to those without. Patients with at least 4 months of systemic treatment lived significantly longer than those who had less ( $>4$ months: median OS 27.5 months, 2 year $54 \%, 5$ year $24 \%$; $<4$ months: median OS 14.3 months, 2 year 25\%, 5 year $4 \%$; $p=0.0004$, Fig. 3). This significant difference persisted in resected patients ( $p=0.003$, supplementary Fig. 1$)$ as well as in unresected patients ( $p=0.023$, supplementary Fig. 2).

A comparison of combined treatment modalities showed that patients who received $>4$ months of systemic treat- ment followed by $>40$ Gy radiation therapy had an overall survival advantage (median OS 28.3 months versus 14.3 months, $p=0.0002$, Fig. 4). Again, the difference persisted both in resected $(p=0.003)$ and unresected patients $(p=0.020)$.

Prognostically relevant parameters for overall survival were analyzed separately for resected and unresected patients (Table 3). In resected patients involvement of either duodenum, spleen or adrenal glands was a significant factor in univariate analysis $(p=0.046)$ but no longer in the MVA model. In unresected patients, local progression was 
found to be a significant prognosticator in both models (UVA: $p=0.014$; MVA: $\mathrm{HR}=4.132,95 \%$ CI 1.217-14.030, $p=0.023$ ).

Toxicity was mild and well manageable: 67/73 (92\%) patients had no major adverse effects reported, while 6/73 (8\%) patients suffered from radiation induced inflammatory reactions (gastritis, duodenitis, colitis, inflammation of anastomosis).

\section{Discussion}

In this retrospective analysis we could demonstrate that following a minimum of 4 months of systemic treatment, the administration of a total dose higher than $40 \mathrm{~Gy}$ improves OS in patients with nonmetastatic pancreatic cancer.

A total of $40 \mathrm{~Gy}$ was selected as cutoff since practice changing studies conducted by ESPAC [7], the European Organisation for Research and Treatment of Cancer (EORTC) [19] and the Gastrointestinal Tumor Study Group (GITSG) [6] used this regimen (40 Gy in 2 Gy fractions, split course). This amounts to an EQD2 of $32 \mathrm{~Gy}$ assuming a daily loss of $0.6 \mathrm{~Gy}$ during the 2-week break. The median dose of the study published by the Groupe Cooperateur Multidisciplinaire en Oncologie (GERCOR) was 50.4 Gy conventional RT [8]. With the radiation regimens implemented in these trials, median OS ranges between 159 [7] and 243 [8] months were achieved. In retrospective series and population-based cohort studies, the highest reported median OS was 39.9 months with CRT at median total doses of 50.4Gy [20-30]. A National Cancer Database (NCDB) analysis revealing a median OS of 21 months concluded that the optimal dose range for adjuvant RT is possibly between 50 and $55 \mathrm{~Gy}$, while doses $<40 \mathrm{~Gy}$ lead to worse survival [24]. In the current study $31 / 42$ (74\%) of the resected patients received $>40$ Gy. With this treatment schedule, a median OS of 25.5 months was achieved, which is on the upper edge of the published results for CRT arms of prospective studies $[6-8,19]$. Except for the GERCOR trial, these studies applied radiation in split course to potentially large volumes without a centralized quality audit. Apart from the RT concepts, these studies were frequently criticized for their design and statistical analyses so that their results remain disputed.

Adjuvant CT trials report mOS between 22.1 and 28 months [31-34]. Except for one outlier of 48 months [35] this is well in line with our results. A re-analysis of the ESPAC-3 data concluded that the administration of six cycles of adjuvant $\mathrm{CT}$ is more important in terms of OS than an early start after surgery in order to allow for complete recovery [36]. On average the resected patients in our cohort received six cycles of adjuvant $\mathrm{CT}$ and therefore fulfill this prerequisite for the best possible outcome.
A recent comprehensive review including four metaanalyses [37-40] stated that despite of the inconclusiveness of prospective and retrospective studies, adjuvant CRT should be offered to patients with N1 and/or R1 situation after 4-6 months of chemotherapy $[4,30]$. Our data corroborate the idea that 4 months of CT prior to RT improves OS (Fig. 3), whereas neither resection nor lymph node status were significant prognosticators in our cohort. A point of criticism in the above mentioned meta-analyses [37-40] is the disregard for improved local control by CRT. Of note, especially in primarily resectable patients who received adjuvant CT after surgery, the rate of isolated local relapses lies between 18 and 28\% [33-35]. This is also true for the CT arm of the EORTC-40013-22012/ FFCD 9203/GERCOR study with $24 \%$ isolated local relapses reported, compared to $11 \%$ in the CRT arm [8]. This underlines the importance of RT as an effective adjunct local treatment, which reduces the rate of local relapses and their consequences (pain, lower quality of life, higher rate of retreatment) by a factor of 2 . When considering also patients with synchronous distant metastases, the percentage of patients who experience a local relapse is even higher (34 to $82 \%$; [31, 33, 34]). These figures clearly challenge the widely spread notion that CRT should not play a role in resectable pancreatic cancer. In contrast to this assumption, we strongly advocate RT as a powerful tool for the prevention of a local regrowth.

In LAPC patients the mOS in the present analysis was roughly 20 months, which seems to be superior to the mOS rates reported in the majority of clinical trials (8.3-17.4 months; [9-12, 41-43]). Being aware of the fact that a comparison with prospectively collected data is indirect (supplementary Table 2) a critical discussion of our findings has to consider patient selection as well as therapy regimens and toxicity. Reportedly, up to $30 \%$ of the patients develop metastases during induction CT and are therefore considered as unsuitable for subsequent combined CRT [12]. In trials without preceding CT, these patients are however included in the CRT group, which may compromise mOS $[9,10]$. In our cohort of unresected patients, 27/31 (90\%) received systemic treatment before CRT, thus selecting those patients who would potentially benefit most from RT.

CRT was administered in 19 cases mostly as single agent therapy (either gemcitabine or 5-FU). Therefore, toxicity might be higher in prospective studies that apply CT doublets concomitant to irradiation. For example, in the FFCD/SFRO study only $40 \%$ of the patients received CRT as planned. The mOS was 13 months with gemcitabine mono versus 8.6 months with $60 \mathrm{~Gy}$ plus 5 -FU/cisplatinum [9]. Hence, the differences between the current study and prospective trials may - on the one hand-be due to the effectiveness of systemic treatment before CRT, which se- 
lects those patients who are most suitable for locoregional treatment. On the other hand, single agent CRT entails a lower rate of toxicity related treatment interruptions. Hence, in terms of mOS, a less aggressive strategy might be of advantage in this generally frail patient population.

The LAP07 study is the latest prospective randomized control trial on LAPC [11]. After the first randomization 223 patients received gemcitabine weekly and 219 patients the same CT combined with erlotinib. The second randomization step allocated those patients without tumor progression either continue the same systemic treatment (136 patients) or to receive $54 \mathrm{~Gy}$ CRT with capecitabine (133 patients). Median OS, which was the primary endpoint, did not differ significantly between the CRT and the CT arm (15.2 and 16.5 months; [11, 44]). In the current study, 30/31 (97\%) patients with unresectable LAPC received $>40 \mathrm{~Gy}$, which results in a median OS of 20.4 months and 2-year survival rates of $34 \%$. At first sight, our findings seem to be in contrast to the results of the LAP07 study, where no survival difference was noted between patients receiving CRT with 54 Gy versus CT only. However, LAP07-like similar studies listed in supplementary Table 2-tested CRT versus CT alone, whereas the current retrospective analysis compares different dose levels (> vs. <40Gy) within a cohort treated with RT. Thus, since the treatment characteristics of patient groups are different in these analyses, a direct comparison is - to our mind-hardly possible.

The current study is limited by its retrospective nature and the small sample size with 73 patients included between 1998 and 2016. The number of CRT patients in prospective studies is generally small compared to CT trials both in resectable and unresectable situations. In trials with postoperative CRT it is between 21 and 145 patients [6-8, 19] (supplementary Table 1). In 2/4 (50\%) of these studies [6, 8] the number of CRT patients included is smaller than in the current cohort. Considering only resected patients in our cohort $(n=42)$, there is still one study that is smaller [6] and another one with only three patients more than in our collective [8]. In prospective LAPC studies the total number of patients is 23 to $109,6 / 8(75 \%)$ studies include less than the current study. The number of unresected patients in our cohort is 31 , in $2 / 8(25 \%)$ of the mentioned prospected LAPC trials it is lower ([9-12, 42, 43, 45, 46]; supplementary Table 2). Admittedly, a downside of the current analysis is that the group sizes are not well balanced, which reflects daily clinical practice.

Due to the inherent selection bias in retrospective studies disproportionate group sizes may lead to statistical inaccuracies so the results have to be interpreted with caution. The statistics should be understood as largely descriptive of a heterogeneous patient population and cannot be taken as a basis to draw firm conclusions. In addition, patients were treated with a variety of CRT schedules, which reflects clinical practice. Also, there are no clear cutoff criteria for more or less than 4 months of systemic treatment before CRT. This decision was left at the discretion of the treating medical oncologist and discussed in the tumor board. The retrospective application of a 4-month cutoff in our cohort was based on published literature rather than on a strict study design per se [11].

Despite these shortcomings our data confirm that CRT with threshold doses $>40$ Gy after at least 4 months of CT is beneficial both for resected and unresected patients with nonmetastasized pancreatic cancer.

Funding Open access funding provided by Paracelsus Medical University.

\section{Compliance with ethical guidelines}

Conflict of interest S. Bachmayer, G. Fastner, A. Vaszi, W. Iglseder, P. Kopp, J. Holzinger, A. Dinnewitzer, G. Rinnerthaler, S.P. Gampenrieder, K. Emmanuel, R. Greil, F. Sedlmayer and F. Zehentmayr declare that they have no competing interests.

Ethical standards All procedures performed in the study involving human participants were in accordance with the ethical standards of the institutional and/or national research committee and with the 1964 Helsinki declaration and its later amendments or comparable ethical standards. For this type of study formal consent is not required. This article does not contain any studies with animals performed by any of the authors.

Open Access This article is distributed under the terms of the Creative Commons Attribution 4.0 International License (http:// creativecommons.org/licenses/by/4.0/), which permits unrestricted use, distribution, and reproduction in any medium, provided you give appropriate credit to the original author(s) and the source, provide a link to the Creative Commons license, and indicate if changes were made.

\section{References}

1. Malvezzi M, Carioli G, Bertuccio P, Boffetta P, Levi F, La Vecchia C, Negri E (2017) European cancer mortality predictions for the year 2017, with focus on lung cancer. Ann Oncol 28(5):1117-1123. https://doi.org/10.1093/annonc/mdx033

2. American Cancer Society (2016) Cancer facts \& figures 2016. American Cancer Society, Atlanta

3. Khorana AA, Mangu PB, Berlin J, Engebretson A, Hong TS, Maitra A, Mohile SG, Mumber M, Schulick R, Shapiro M, Urba S, Zeh HJ, Katz MHG (2017) Potentially curable pancreatic cancer: American Society of Clinical Oncology clinical practice guideline update. J Clin Oncol 35(20):2324. https://doi.org/10.1200/Jco.2017. 72.4948

4. Silvestris N, Brunetti O, Vasile E, Cellini F, Cataldo I, Pusceddu V, Cattaneo M, Partelli S, Scartozzi M, Aprile G, Casadei Gardini A, Morganti AG, Valentini V, Scarpa A, Falconi M, Calabrese A, Lorusso V, Reni M, Cascinu S (2017) Multimodal treatment of resectable pancreatic ductal adenocarcinoma. Crit Rev Oncol Hematol 111:152-165. https://doi.org/10.1016/j.critrevonc.2017.01.015

5. Seufferlein T, Porzner M, Becker T, Budach V, Ceyhan G, Esposito I, Fietkau R, Follmann M, Friess H, Galle P, Geissler M, Glanemann M, Gress T, Heinemann V, Hohenberger W, Hopt U, 
Izbicki J, Klar E, Kleeff J, Kopp I, Kullmann F, Langer T, Langrehr J, Lerch MM, Lohr M, Luttges J, Lutz M, Mayerle J, Michl P, Moller P, Molls M, Munter M, Nothacker M, Oettle H, Post S, Reinacher-Schick A, Rocken C, Roeb E, Saeger H, Schmid R, Schmiegel W, Schoenberg M, Siveke J, Stuschke M, Tannapfel A, Uhl W, Unverzagt S, van Oorschot B, Vashist Y, Werner J, Yekebas E (2013) S3-guideline exocrine pancreatic cancer. Z Gastroenterol 51(12):1395-1440. https://doi.org/10.1055/s-0033-1356220

6. Kalser MH, Ellenberg SS (1985) Pancreatic cancer. Adjuvant combined radiation and chemotherapy following curative resection. Arch Surg 120(8):899-903

7. Neoptolemos JP, Stocken DD, Friess H, Bassi C, Dunn JA, Hickey H, Beger H, Fernandez-Cruz L, Dervenis C, Lacaine F, Falconi M, Pederzoli P, Pap A, Spooner D, Kerr DJ, Buchler MW (2004) A randomized trial of chemoradiotherapy and chemotherapy after resection of pancreatic cancer. N Engl J Med 350(12):1200-1210. https://doi.org/10.1056/NEJMoa032295

8. Van Laethem JL, Hammel P, Mornex F, Azria D, Van Tienhoven G, Vergauwe P, Peeters M, Polus M, Praet M, Mauer M, Collette L, Budach V, Lutz M, Van Cutsem E, Haustermans K (2010) Adjuvant gemcitabine alone versus gemcitabine-based chemoradiotherapy after curative resection for pancreatic cancer: a randomized EORTC-40013-22012/FFCD-9203/GERCOR phase II study. J Clin Oncol 28(29):4450-4456. https://doi.org/10.1200/JCO.2010. 30.3446

9. Chauffert B, Mornex F, Bonnetain F, Rougier P, Mariette C, Bouche O, Bosset JF, Aparicio T, Mineur L, Azzedine A, Hammel P, Butel J, Stremsdoerfer N, Maingon P, Bedenne L (2008) Phase III trial comparing intensive induction chemoradiotherapy (60 Gy, infusional 5-FU and intermittent cisplatin) followed by maintenance gemcitabine with gemcitabine alone for locally advanced unresectable pancreatic cancer. Definitive results of the 2000-01 FFCD/SFRO study. Ann Oncol 19(9):1592-1599. https://doi.org/ 10.1093/annonc/mdn281

10. Loehrer PJ Sr., Feng Y, Cardenes H, Wagner L, Brell JM, Cella D, Flynn P, Ramanathan RK, Crane CH, Alberts SR, Benson AB 3rd (2011) Gemcitabine alone versus gemcitabine plus radiotherapy in patients with locally advanced pancreatic cancer: an Eastern Cooperative Oncology Group trial. J Clin Oncol 29(31):4105-4112. https://doi.org/10.1200/JCO.2011.34.8904

11. Hammel P, Huguet F, van Laethem JL, Goldstein D, Glimelius B, Artru P, Borbath I, Bouche O, Shannon J, Andre T, Mineur L, Chibaudel B, Bonnetain F, Louvet C (2016) Effect of chemoradiotherapy vs chemotherapy on survival in patients with locally advanced pancreatic cancer controlled after 4 months of gemcitabine with or without Erlotinib: the LAP07 randomized clinical trial. JAMA 315(17):1844-1853. https://doi.org/10.1001/jama. 2016.4324

12. Huguet F, Andre T, Hammel P, Artru P, Balosso J, Selle F, Deniaud-Alexandre E, Ruszniewski P, Touboul E, Labianca R, de Gramont A, Louvet C (2007) Impact of chemoradiotherapy after disease control with chemotherapy in locally advanced pancreatic adenocarcinoma in GERCOR phase II and III studies. J Clin Oncol 25(3):326-331. https://doi.org/10.1200/JCO.2006.07.5663

13. Verbeke CS, Menon KV (2009) Redefining resection margin status in pancreatic cancer. HPB (Oxford) 11(4):282-289. https://doi.org/ 10.1111/j.1477-2574.2009.00055.x

14. Verbeke CS, Leitch D, Menon KV, McMahon MJ, Guillou PJ, Anthoney A (2006) Redefining the R1 resection in pancreatic cancer. Br J Surg 93(10):1232-1237. https://doi.org/10.1002/bjs.5397

15. Emami B, Lyman J, Brown A, Coia L, Goitein M, Munzenrider JE, Shank B, Solin LJ, Wesson M (1991) Tolerance of normal tissue to therapeutic irradiation. Int J Radiat Oncol Biol Phys 21(1):109-122

16. Hall EJ, Giaccia A (2006) Time, dose, and fractionation in radiotherapy. In: Hall EJ (ed) Radiobiology for the radiologist, 6th edn. Lippincott Williams \& Wilkins, Philadelphia, pp 378-398
17. Joiner MC, Bentzen SM (2009) Fractionation: the linear-quadratic approach. In: Joiner MC (ed) Basic clinical radiobiology, 4th edn. Edward Arnold, London, pp 102-120

18. Unkel S, Belka C, Lauber K (2016) On the analysis of clonogenic survival data: statistical alternatives to the linear-quadratic model. Radiat Oncol 11:11. https://doi.org/10.1186/s13014-016-0584-z

19. Klinkenbijl JH, Jeekel J, Sahmoud T, van Pel R, Couvreur ML, Veenhof CH, Arnaud JP, Gonzalez DG, de Wit LT, Hennipman A, Wils J (1999) Adjuvant radiotherapy and 5-fluorouracil after curative resection of cancer of the pancreas and periampullary region: phase III trial of the EORTC gastrointestinal tract cancer cooperative group. Ann Surg 230(6):776-782 (discussion 782-774)

20. Herman JM, Swartz MJ, Hsu CC, Winter J, Pawlik TM, Sugar E, Robinson R, Laheru DA, Jaffee E, Hruban RH, Campbell KA, Wolfgang CL, Asrari F, Donehower R, Hidalgo M, Diaz LA Jr., Yeo C, Cameron JL, Schulick RD, Abrams R (2008) Analysis of fluorouracil-based adjuvant chemotherapy and radiation after pancreaticoduodenectomy for ductal adenocarcinoma of the pancreas: results of a large, prospectively collected database at the Johns Hopkins Hospital. J Clin Oncol 26(21):3503-3510. https://doi.org/10. 1200/JCO.2007.15.8469

21. Corsini MM, Miller RC, Haddock MG, Donohue JH, Farnell MB, Nagorney DM, Jatoi A, McWilliams RR, Kim GP, Bhatia S, Iott MJ, Gunderson LL (2008) Adjuvant radiotherapy and chemotherapy for pancreatic carcinoma: the Mayo Clinic experience (1975-2005). J Clin Oncol 26(21):3511-3516. https://doi.org/ 10.1200/JCO.2007.15.8782

22. Sohn TA, Yeo CJ, Cameron JL, Koniaris L, Kaushal S, Abrams RA, Sauter PK, Coleman J, Hruban RH, Lillemoe KD (2000) Resected adenocarcinoma of the pancreas-616 patients: results, outcomes, and prognostic indicators. J Gastrointest Surg 4(6):567-579

23. Morganti AG, Falconi M, van Stiphout RG, Mattiucci GC, Alfieri S, Calvo FA, Dubois JB, Fastner G, Herman JM, Maidment BW 3rd, Miller RC, Regine WF, Reni M, Sharma NK, Ippolito E, Valentini V (2014) Multi-institutional pooled analysis on adjuvant chemoradiation in pancreatic cancer. Int J Radiat Oncol Biol Phys 90(4):911-917. https://doi.org/10.1016/j.ijrobp.2014.07.024

24. Hall WA, Colbert LE, Liu Y, Gillespie T, Lipscomb J, Hardy C, Kooby DA, Prabhu RS, Kauh J, Landry JC (2013) The influence of adjuvant radiotherapy dose on overall survival in patients with resected pancreatic adenocarcinoma. Cancer 119(12):2350-2357. https://doi.org/10.1002/cner.28047

25. Kooby DA, Gillespie TW, Liu Y, Byrd-Sellers J, Landry J, Bian J, Lipscomb J (2013) Impact of adjuvant radiotherapy on survival after pancreatic cancer resection: an appraisal of data from the national cancer data base. Ann Surg Oncol 20(11):3634-3642. https:// doi.org/10.1245/s10434-013-3047-x

26. Lim YJ, Kim K, Chie EK, Kim B, Ha SW (2015) Role of adjuvant radiotherapy in left-sided pancreatic cancer-populationbased analysis with propensity score matching. J Gastrointest Surg 19(12):2183-2191. https://doi.org/10.1007/s11605-015-2941-x

27. Mellon EA, Springett GM, Hoffe SE, Hodul P, Malafa MP, Meredith KL, Fulp WJ, Zhao X, Shridhar R (2014) Adjuvant radiotherapy and lymph node dissection in pancreatic cancer treated with surgery and chemotherapy. Cancer 120(8):1171-1177. https://doi. org/10.1002/cncr.28543

28. Rutter CE, Park HS, Corso CD, Lester-Coll NH, Mancini BR, Yeboa DN, Johung KL (2015) Addition of radiotherapy to adjuvant chemotherapy is associated with improved overall survival in resected pancreatic adenocarcinoma: an analysis of the National Cancer Data Base. Cancer 121(23):4141-4149. https://doi.org/10. $1002 /$ cncr.29652

29. Sugawara A, Kunieda E (2014) Effect of adjuvant radiotherapy on survival in resected pancreatic cancer: a propensity score surveillance, epidemiology, and end results database analysis. J Surg Oncol 110(8):960-966. https://doi.org/10.1002/jso.23752 
30. Xia Z, Jia X, Chen K, Li D, Xie J, Xu H, Mao Y (2016) Survival benefits from postoperative radiation therapy on lymph node positive patients with pancreatic adenocarcinoma. Oncotarget 7(29):46646-46652. https://doi.org/10.18632/oncotarget.9620

31. Oettle H, Post S, Neuhaus P, Gellert K, Langrehr J, Ridwelski K, Schramm H, Fahlke J, Zuelke C, Burkart C, Gutberlet K, Kettner E, Schmalenberg H, Weigang-Koehler K, Bechstein WO, Niedergethmann M, Schmidt-Wolf I, Roll L, Doerken B, Riess H (2007) Adjuvant chemotherapy with gemcitabine vs observation in patients undergoing curative-intent resection of pancreatic cancer: a randomized controlled trial. JAMA 297(3):267-277. https://doi.org/ 10.1001/jama.297.3.267

32. Neoptolemos JP, Stocken DD, Bassi C, Ghaneh P, Cunningham D, Goldstein D, Padbury R, Moore MJ, Gallinger S, Mariette C, Wente MN, Izbicki JR, Friess H, Lerch MM, Dervenis C, Olah A, Butturini G, Doi R, Lind PA, Smith D, Valle JW, Palmer DH, Buckels JA, Thompson J, McKay CJ, Rawcliffe CL, Buchler MW, European Study Group for Pancreatic C (2010) Adjuvant chemotherapy with fluorouracil plus folinic acid vs gemcitabine following pancreatic cancer resection: a randomized controlled tria. JAMA 304(10):1073-1081. https://doi.org/10.1001/jama.2010.1275

33. Neoptolemos JP, Palmer DH, Ghaneh P, Psarelli EE, Valle JW, Halloran CM, Faluyi O, O'Reilly DA, Cunningham D, Wadsley J, Darby S, Meyer T, Gillmore R, Anthoney A, Lind P, Glimelius B, Falk S, Izbicki JR, Middleton GW, Cummins S, Ross PJ, Wasan H, McDonald A, Crosby T, Ma YT, Patel K, Sherriff D, Soomal R, Borg D, Sothi S, Hammel P, Hackert T, Jackson R, Buchler MW, European Study Group for Pancreatic C (2017) Comparison of adjuvant gemcitabine and capecitabine with gemcitabine monotherapy in patients with resected pancreatic cancer (ESPAC-4): a multicentre, open-label, randomised, phase 3 trial. Lancet 389(10073):1011-1024. https://doi.org/10.1016/S01406736(16)32409-6

34. Sinn M, Bahra M, Liersch T, Gellert K, Messmann H, Bechstein W, Waldschmidt D, Jacobasch L, Wilhelm M, Rau BM, Grutzmann R, Weinmann A, Maschmeyer G, Pelzer U, Stieler JM, Striefler JK, Ghadimi M, Bischoff S, Dorken B, Oettle H, Riess H (2017) CONKO-005: adjuvant chemotherapy with Gemcitabine plus erlotinib versus gemcitabine alone in patients after R0 resection of pancreatic cancer: a Multicenter randomized phase III trial. J Clin Oncol 35(29):3330-3337. https://doi.org/10.1200/JCO.2017.72. 6463

35. Uesaka K, Boku N, Fukutomi A, Okamura Y, Konishi M, Matsumoto I, Kaneoka Y, Shimizu Y, Nakamori S, Sakamoto H, Morinaga S, Kainuma O, Imai K, Sata N, Hishinuma S, Ojima H, Yamaguchi R, Hirano S, Sudo T, Ohashi Y, Group JS (2016) Adjuvant chemotherapy of S-1 versus gemcitabine for resected pancreatic cancer: a phase 3, open-label, randomised, non-inferiority trial (JASPAC 01). Lancet 388(10041):248-257. https://doi.org/10. 1016/S0140-6736(16)30583-9

36. Valle JW, Palmer D, Jackson R, Cox T, Neoptolemos JP, Ghaneh P, Rawcliffe CL, Bassi C, Stocken DD, Cunningham D, O'Reilly D, Goldstein D, Robinson BA, Karapetis C, Scarfe A, Lacaine F, Sand J, Izbicki JR, Mayerle J, Dervenis C, Olah A, Butturini G, Lind PA, Middleton MR, Anthoney A, Sumpter K, Carter R, Buchler MW (2014) Optimal duration and timing of adjuvant chemotherapy after definitive surgery for ductal adenocarcinoma of the pancreas: ongoing lessons from the ESPAC-3 study. J Clin Oncol 32(6):504-512. https://doi.org/10.1200/JCO.2013.50.7657
37. Stocken DD, Buchler MW, Dervenis C, Bassi C, Jeekel H, Klinkenbijl JH, Bakkevold KE, Takada T, Amano H, Neoptolemos JP (2005) Meta-analysis of randomised adjuvant therapy trials for pancreatic cancer. Br J Cancer 92(8):1372-1381. https://doi.org/ 10.1038/sj.bjc. 6602513

38. Butturini G, Stocken DD, Wente MN, Jeekel H, Klinkenbijl JH, Bakkevold KE, Takada T, Amano H, Dervenis C, Bassi C, Buchler MW, Neoptolemos JP (2008) Influence of resection margins and treatment on survival in patients with pancreatic cancer: metaanalysis of randomized controlled trials. Arch Surg 143(1):75-83. https://doi.org/10.1001/archsurg.2007.17 (discussion 83)

39. Ren F, Xu YC, Wang HX, Tang L, Ma Y (2012) Adjuvant chemotherapy, with or without postoperative radiotherapy, for resectable advanced pancreatic adenocarcinoma: continue or stop? Pancreatology 12(2):162-169. https://doi.org/10.1016/j.pan.2012. 02.002

40. Liao WC, Chien KL, Lin YL, Wu MS, Lin JT, Wang HP, Tu YK (2013) Adjuvant treatments for resected pancreatic adenocarcinoma: a systematic review and network meta-analysis. Lancet Oncol 14(11):1095-1103. https://doi.org/10.1016/S14702045(13)70388-7

41. Klaassen DJ, MacIntyre JM, Catton GE, Engstrom PF, Moertel CG (1985) Treatment of locally unresectable cancer of the stomach and pancreas: a randomized comparison of 5-fluorouracil alone with radiation plus concurrent and maintenance 5-fluorouracil-an Eastern Cooperative Oncology Group study. J Clin Oncol 3(3):373-378. https://doi.org/10.1200/JCO.1985.3.3.373

42. Mukherjee S, Hurt CN, Bridgewater J, Falk S, Cummins S, Wasan H, Crosby T, Jephcott C, Roy R, Radhakrishna G, McDonald A, Ray R, Joseph G, Staffurth J, Abrams RA, Griffiths G, Maughan T (2013) Gemcitabine-based or capecitabine-based chemoradiotherapy for locally advanced pancreatic cancer (SCALOP): a multicentre, randomised, phase 2 trial. Lancet Oncol 14(4):317-326. https:// doi.org/10.1016/S1470-2045(13)70021-4

43. Wilson JM, Fokas E, Dutton SJ, Patel N, Hawkins MA, Eccles C, Chu KY, Durrant L, Abraham AG, Partridge M, Woodward M, O’Neill E, Maughan T, McKenna WG, Mukherjee S, Brunner TB (2016) ARCII: A phase II trial of the HIV protease inhibitor Nelfinavir in combination with chemoradiation for locally advanced inoperable pancreatic cancer. Radiother Oncol 119(2):306-311. https://doi.org/10.1016/j.radonc.2016.03.021

44. Brunner T, Fokas E (2016) The results of the LAP07 trial should not be misunderstood as the end of chemoradiotherapy in pancreatic cancer. Strahlenther Onkol 192(12):956-958. https://doi.org/ 10.1007/s00066-016-1058-9

45. Moureau-Zabotto L, Phelip JM, Afchain P, Mineur L, Andre T, Vendrely V, Lledo G, Dupuis O, Huguet F, Touboul E, Balosso J, Louvet C (2008) Concomitant administration of weekly oxaliplatin, fluorouracil continuous infusion, and radiotherapy after 2 months of gemcitabine and oxaliplatin induction in patients with locally advanced pancreatic cancer: a Groupe Coordinateur Multidisciplinaire en Oncologie phase II study. J Clin Oncol 26(7):1080-1085. https://doi.org/10.1200/JCO.2007.12.8223

46. Louvet C, Andre T, Lledo G, Hammel P, Bleiberg H, Bouleuc C, Gamelin E, Flesch M, Cvitkovic E, de Gramont A (2002) Gemcitabine combined with oxaliplatin in advanced pancreatic adenocarcinoma: final results of a GERCOR multicenter phase II study. J Clin Oncol 20(6):1512-1518. https://doi.org/10.1200/JCO.2002. 20.6.1512 